\title{
Effect of Bring-Your-Own-Device Program on Flipped Learning in Higher Education Students
}

\author{
Santiago Pozo Sánchez ${ }^{1}{ }^{\mathbb{D}}$, Jesús López-Belmonte ${ }^{1, *}{ }^{\mathbb{D}}$, Antonio-José Moreno-Guerrero ${ }^{1}{ }^{\mathbb{D}}$, \\ José María Sola Reche ${ }^{2}$ and Arturo Fuentes Cabrera ${ }^{1}$ \\ 1 Department of Didactics and School Organization, University of Granada, 18071 Granada, Spain; \\ santiagopozo@correo.ugr.es (S.P.S.); ajmoreno@ugr.es (A.-J.M.-G.); arturofuentes@ugr.es (A.F.C.) \\ 2 Department of General Didactics and Specific Didactics, University of Alicante, 03080 Alicante, Spain; \\ jsola@ua.es \\ * Correspondence: jesuslopez@ugr.es
}

Received: 3 April 2020; Accepted: 1 May 2020; Published: 4 May 2020

\begin{abstract}
The "bring your own device" (BYOD) program is positioned as one of the fastest-emerging methods to solve accessibility problems in the flipped learning methodology. The objective of the study is to analyze the potential of a training plan through inverted learning using the BYOD program compared to inverted learning without BYOD. A quasi-experimental design was carried out on a sample of 118 Higher Education students. A questionnaire was used as an instrument for data collection. The results show that the assessments of the study groups, both control and experimental, are at medium-high levels, which shows a significant incidence of the teaching and learning methodologies applied in both groups. There are only three dimensions in which a distance is observed between the groups' assessments: motivation and autonomy, which were better valued by the experimental group, and class time, which was better valued by the control group. The study concludes that there are no great differences between the teaching methodologies applied in the groups that were subjected to experimentation, except in terms of motivation and autonomy, making these methodologies reliable for the development of these dimensions.
\end{abstract}

Keywords: emerging methodology; educational innovation; flipped learning; BYOD; academic indicators; academic improvements; educational experimentation; higher education; students

\section{Introduction}

Currently, the number of studies investigating the attitudinal, psychosocial, and academic effects of flipped learning has increased. The latest scientific research describes flipped learning as a methodology capable of developing the teaching and learning process effectively.

In the present investigation, in order to investigate those factors that may affect the instructional process, as well as in the different areas discussed above, the general objective was to analyze the potential of a training plan through flipped learning using the "bring your own device" (BYOD) program over another process of flipped learning without using that program. The following research questions (RQ) arise from this objective with the purpose of specifying and conducting the study:

- $\quad$ RQ1: Does the use of the BYOD program influence the motivation of students?

- RQ2: Does the use of the BYOD program influence the interaction of students with the teacher?

- RQ3: Does the use or not of the BYOD program influence the interaction of students with didactic contents?

- RQ4: Does the use of the BYOD program influence the interaction between students?

- RQ5: Does the use of the BYOD program influence the autonomy of students? 
- RQ6: Does the use of the BYOD program influence the collaboration of students?

- RQ7: Does the use of the BYOD program influence the level of content deepening?

- RQ8: Does the use of the BYOD program influence the students' degree of problem solving?

- $\quad$ RQ9: Does the use of the BYOD program influence the degree of class time by students?

- RQ10: Does the use of the BYOD program influence the ratings obtained by students?

\section{Flipped Learning and the BYOD Program: A Binomial for Learning Optimization}

The current educational paradigm is based on the need to adapt teaching methods to the particularities of today's students [1,2]. Along this line, the flipped learning methodology manages to use information and communication technologies (ICT) as the main tools of the teaching and learning process [3], granting the role of learning to the student themselves [4]. This methodology was born precisely as a response to the needs of students who had problems attending class regularly. Thanks to the contributions of teachers Aaron Sams and Jonathan Bergmann, these students could receive didactic content through audiovisual means [5]. From the year of its birth in 2012, flipped learning has evolved and adapted to the novelties of the educational context, currently having a large number of users from the teaching community [6,7].

The methodological foundation of flipped learning focuses on turning the learning moment between the classroom and outside the sphere of the classroom [8]. The teacher uses the usual class schedule to guide the students and to carry out practical activities [9]. On the other hand, the student invests their extracurricular period in working with conceptual and procedural content using digital tools $[10,11]$. In this way, the student stars in the training process $[12,13]$ and adapts access to content autonomously and appropriately to their needs $[14,15]$.

Conceptually, the flipped classroom is the mixed space (physical and digital) in which the flipped learning methodology is carried out in educational contexts, that is, it is characterized by a greater semantic concretion than the concept of flipped learning [5,7]. In contrast to the concept of flipped classroom, flipped learning encompasses its methodological implementation in any teaching-learning process, regardless of the field, discipline, educational level, and type of student. Therefore, the flipped classroom is the practical implementation of the flipped learning methodology within the context of an educational center [5].

Research on flipped learning focuses its benefits on the high degree of motivation and participation of students [16]. Motivation in education is understood as the factors that encourage students to be attentive to the teacher's explanations, to have an interest in asking various questions, and to address all the doubts that they have $[17,18]$. It also promotes a climate of cooperation and collaboration between them during activities [19]. This context fosters student socialization [20] and the ability to solve problems at the individual and collective level [21]. In this way, the flipped learning methodology enables students to assimilate the contents [22] and achieve the teaching objectives more easily [23] and achieve better grades in the processes of evaluation [24,25].

However, despite all the benefits outlined in flipped learning, this methodology also has some limitations. Some research has found that it is especially problematic with students with low capacity for abstraction [26] and with poor problem solving [21,27]. Likewise, this methodology can cause problems with students who have difficulties in accessibility, in the use of learning platforms or in the availability of technological tools $[28,29]$. The use of ICT is essential in the application of flipped learning, and sometimes it is difficult for students from low sociocultural contexts to access digital tools [30].

Regarding the latter limitation, flipped learning offers a multitude of variants that allow solving the different problems that the teaching process may generate. One of these variants is the combination of the flipped learning methodology with the "bring your own device" (BYOD) program, a focus on the application of methodologies that is very popular in secondary education and higher education [31]. Although the BYOD program is born in relation to business and the world of work, its application in the educational context involves an organized network in which it is the student who brings their own 
digital devices and technological tools to the educational center [32], mainly computers, smartphones, and tablets [33].

The use of the BYOD program has a positive impact in the educational context [34], in a way that allows for individualization and flexibility of the teaching and learning process [35]. The fact that students can use their own devices reverts to a positive attitude from both students [36] and teachers towards said model [37]. Likewise, thanks to the connectivity that digital devices allow, collaboration between students and the collective construction of knowledge are encouraged [35]. In this way, the application of the BYOD program in flipped learning optimizes student performance [38], causing an improvement in their grades and promoting collaborative and self-directed learning [39]. Additionally, this combination allows students to carry out activities effectively in any context [24] in a way that is productive, since they are familiar with the configuration of their personal devices [40].

The application of the BYOD program facilitates the storage and recovery of files; however, the portability of the devices causes negative limitations related to weight and size [40]. In addition, the application of this model allows students to understand the concepts more easily and promote understanding collaborative discussions to build learning [41], although it requires adequate teacher training for it to develop appropriately [42]. Positive repercussions are also observed in student learning, which can affect student behavior in the teaching and learning process [34], although many of the student may refuse to use it, due to the possible loss or device damage [43].

On the other hand, the most negative aspects of using the BYOD program in the flipped classroom are related to the lack of support from educational institutions or the parents' group so that students can use their own devices in the classroom [37]. Some students are not comfortable regularly taking their devices to class or sharing them with their classmates [44]. Problems related to the use of technology itself have also been found, such as the availability of internet access, battery power, lack of infrastructure or low professional development of teachers [35].

\section{Materials and Methods}

\subsection{Research Design}

The study was developed using a quantitative research methodology using a quasi-experimental design, following the recommendations of the experts $[45,46]$. In addition, a reported analysis model of impact studies was used in order to follow an analytical structure validated by the scientific community [7,47-52].

The investigation required the configuration of two study groups (control group and experimental group). Each of them carried out a different flipped learning variant. The control group carried out flipped learning without the BYOD program, and the experimental group carried out flipped learning complemented with the BYOD program. This allowed articulating two study variables. The variant of flipped learning carried out was established as an independent variable. The dependent variable is the incidence originating from the different indicators under study.

In this research process, only one measurement was taken, and it took place at the end of the training plan. Therefore, the design of this experimentation at the instructional level acquires posttest cataloging.

\subsection{Participants}

The sample was made up of a total of 118 Spanish university students. As sociodemographic singularities of these subjects, it was determined that $38.14 \%$ are men and the rest are women, with an average age of 19.7 years $(\mathrm{SD}=2.1)$. These participants were chosen using an intentional sampling technique. Impact studies certify that the sample size to carry out this type of research does not condition or limit its performance and subsequent establishment of relevant and pertinent conclusions for the scientific literature $[29,53]$. 
The participants were divided into a control group and an experimental group, respecting the class group to which they belong. The type of treatment was applied in a probabilistic way (control group = flipped learning without BYOD; experimental group = flipped learning with BYOD) (Table 1).

Table 1. Groups' composition.

\begin{tabular}{cccccc}
\hline Group & $\mathbf{n}$ & Composition & Pretest & Treatment & Postest \\
\hline 1- Control & 59 & Natural & - & $X$ & $\mathrm{O}_{1}$ \\
2- Experimental & 59 & Natural & - & $X$ & $\mathrm{O}_{2}$ \\
\hline
\end{tabular}

\subsection{Study Dimensions}

To ensure the relevance of the results and delve into the findings presented on the state of the question, the catalog of dimensions used in previous studies indexed in specialized databases with the impact index of Journal Citation Reports (JCR) and Scopus was followed [7,47-49,51,52,54].

The dimensions used are specified below in order to facilitate the interpretation of the results:

- Social-educational: includes the items related to sex, age, city, nationality, religion, students' course, and methodological aspects;

- Motivation: includes items related to the level of motivation of students during the training process;

- Interactions: includes the items related to the different interactions of the students (with the teacher, with the contents and between the different students) during the instruction;

- Autonomy: includes the items related to the level of autonomy reached by the students in the displayed training;

- Collaboration: includes the items related to collaboration and teamwork carried out by the students in the formative action;

- Deepening in the contents: includes the items related to the degree of projection that the contents taught during the teaching and learning process achieve;

- Problem resolution: includes the items related to the students' competence to solve the problems arising from the training plan;

- Class time: includes the items related to the temporary use of face-to-face sessions developed during the instruction period;

- Ratings: includes the items related to the perception of the ratings reached by the students;

- Teacher ratings: includes the items related to the ratings registered by the teacher in the assessment tests carried out by the students.

\subsection{Instrument}

The instrument used for data collection was an ad hoc questionnaire. This tool was made after searching and analyzing other instruments on the state addressed by this study, with the purpose of specifying an instrument that is adapted to the particularities of the research context [7,54-57]. The designed questionnaire is made up of 35 items, cataloged in the dimensions previously described (socioeducational $=9$ items; motivation $=3$ items; teacher-student interactions $=2$ items; student-content interactions $=2$ items; student-student interactions $=2$ items; autonomy $=3$ items; collaboration $=3$ items; deepening in the contents $=2$ items; problem resolution $=2$ items; class time $=2$ items; ratings $=3$ items; teacher ratings $=2$ items). Most of the questions used a Likert rating scale of 1 to 4 points (from most negative to most positive) and others with a closed choice.

The validation of the questionnaire was first produced by a group of experts in emerging methodologies who carried out a Delphi method. These specialists analyzed each one of the questions in particular and the tool as a whole and issued a favorable judgment $(\mathrm{M}=5.02 ; \mathrm{SD}=0.63$; $\mathrm{min}=$ 1 ; $\max =6$ ). They also offered different recommendations to improve the instrument. The feedback 
received was analyzed through the Kappa of Fleiss (K) and W of Kendall (W) statistics, revealing an adequate level of agreement and relevance $(K=0.82 ; \mathrm{W}=0.84)$ of the observations of these judges.

Furthermore, the questionnaire was subjected to an exploratory factor analysis with the principal components method. Bartlett's test of sphericity was calculated that reflected dependence between the study variables $(2249.51 ; p<0.001)$ and the Kaiser-Meyer-Olkin test that determined an adequate adequacy of the sample $(\mathrm{KMO}=0.83)$. Similarly, the reliability of the instrument in question was decreed by means of different statistics that showed adequate internal consistency (Cronbach's alpha- $\alpha$ $=0.86$; compound reliability $=0.84$; average variance extracted $=0.81$ ).

\subsection{Procedure}

The experimentation consisted of developing a training plan through the flipped learning methodology from two perspectives: a flipped learning based on the use of digital devices in the classroom and a flipped learning complemented by the BYOD program. The control group students only had the technological resources existing in the educational institution, that is, an interactive whiteboard in the main classroom and a computer in the computer room. By contrast, the control group students could bring their own electronic device to class to use as a personal technological complement, mainly highlighting the use of laptops, smartphones, and tablets. In this case, the teacher had a list of registered devices that had previously been reviewed and that met the technical requirements.

This training program covered 12 sessions, following the proper structure that characterizes this teaching and learning methodology. Specifically, the students, before going to the face-to-face class, had all the audiovisual teaching material stored in a web repository available so that it could be previewed. In this way, the time outside the classroom was allocated to the visualization of the multimedia material to carry out a first approach to the learning contents. The role of the teacher in both study groups focused on the orientation and guidance of the students towards learning. The student played a leading role focused on autonomy, self-regulation, and collaborative learning.

The contents treated during the sessions were the same for the control group and for the experimental group. These contents were related to teaching and the teaching profession, curriculum planning, and the development of the educational curriculum:

- Didactic interaction and communication between the teacher and the students;

- Curriculum and action plan;

- Educational goals and purposes;

- Educational content and skills;

- Teaching evaluation;

- Class direction for teaching;

- Teaching-learning models;

- Personalization in teaching;

- Direct teaching with the whole class;

- Teaching through collaborative-cooperative work groups;

- Teaching through inquiry and discovery and autonomous work;

- Development of creative thinking in the classroom.

Once the instruction process was completed, the measurement phase took place with the application of the questionnaire. All the data collected were processed at the statistical level to allow for the effective achievement of the study objective and to achieve a timely response to each of the questions asked.

\subsection{Data Analysis}

The analysis of the collected data was carried out with the Statistical Package for the Social Sciences (SPSS) v25 (IBM Corp., Armonk, NY, USA, 2017). In this analysis, the mean (M) and standard 
deviation (SD) were calculated, as well as other tests to determine the distribution trend by means of skewness $\left(\mathrm{S}_{\mathrm{kw}}\right)$ and kurtosis $\left(\mathrm{K}_{\mathrm{me}}\right)$. The comparison between the group means was carried out with the Student's $t$-test $\left(t_{n 1+n 2-2}\right)$. The size of the effect caused was determined with Cohen's $d$ and the biserial correlation $\left(r_{x y}\right)$. We worked with a $p<0.05$ to establish statistically significant differences.

\section{Results}

The data collected in the descriptive analysis show that the measures given are even, both in the control group and in the experimental group, with the average being between 2.5 and 3 . This shows that the ratings by both groups in relation to the applied flipped learning modalities are similar. The data provide a normal distribution of the sample [58]. The standard deviation in most of the dimensions offers a trend of dispersed response by the students, except in the dimensions or class-time and ratings of the control group, and the dimensions or student-student, autonomy, collaboration, resolution, ratings, and teacher ratings, where the responses are more even. Kurtosis is placid in all the study dimensions, both in the control group and the experimental group (Table 2).

Table 2. Results obtained for the control group and experimental group dimensions.

\begin{tabular}{|c|c|c|c|c|c|c|c|c|c|}
\hline & \multirow[b]{2}{*}{ Dimensions } & \multicolumn{4}{|c|}{ Likert Scale n (\%) } & \multicolumn{4}{|c|}{ Parameters } \\
\hline & & None & Few & Enough & Completely & $\mathbf{M}$ & SD & $\mathrm{S}_{\mathbf{k w}}$ & $\mathbf{K}_{\text {me }}$ \\
\hline \multirow{11}{*}{$\begin{array}{l}\text { Control } \\
\text { Group }\end{array}$} & Motivation & $9(15.3)$ & $12(20.3)$ & $21(35.6)$ & $17(28.8)$ & 2.78 & 1.03 & -0.407 & -0.955 \\
\hline & Teacher-student & $8(13.6)$ & $12(20.3)$ & $21(35.6)$ & $18(30.5)$ & 2.83 & 1.02 & -0.455 & -0.876 \\
\hline & Student-content & $9(15.3)$ & $10(16.9)$ & $23(39)$ & $17(28.8)$ & 2.81 & 1.02 & -0.506 & -0.816 \\
\hline & Student-student & $10(16.9)$ & $10(16.9)$ & $22(37.3)$ & $17(28.8)$ & 2.78 & 1.05 & -0.460 & -0.945 \\
\hline & Autonomy & 11(18.6) & $10(16.9)$ & $23(39)$ & $15(25.4)$ & 2.71 & 1.05 & -0.402 & -0.994 \\
\hline & Collaboration & $10(16.9)$ & $11(18.6)$ & $22(37.3)$ & $16(27.1)$ & 2.75 & 1.04 & -0.406 & -0.971 \\
\hline & Deepening & $10(16.9)$ & $10(16.9)$ & $23(39)$ & $16(27.1)$ & 2.76 & 1.04 & -0.454 & -0.910 \\
\hline & Resolution & $9(15.3)$ & 11(18.6) & $24(40.7)$ & $15(25.4)$ & 2.76 & 1.01 & -0.446 & -0.811 \\
\hline & Class time & $4(6.8)$ & $12(20.3)$ & $17(28.8)$ & $26(44.1)$ & 3.10 & 0.956 & -0.694 & -0.620 \\
\hline & Ratings $^{a}$ & $9(15.3)$ & $15(25.4)$ & $22(37.3)$ & $13(22)$ & 2.66 & 0.993 & -0.246 & -0.933 \\
\hline & Teacher ratings ${ }^{a}$ & $10(16.9)$ & $14(23.7)$ & $21(35.6)$ & $14(23.7)$ & 2.66 & 1.20 & -0.254 & -1.03 \\
\hline \multirow{11}{*}{$\begin{array}{l}\text { Experimental } \\
\text { Group }\end{array}$} & Motivation & $5(8.5)$ & $15(25.4)$ & $15(25.4)$ & $24(40.7)$ & 2.98 & 1.01 & -0.487 & -0.998 \\
\hline & Teacher-student & $7(11.9)$ & $14(23.7)$ & $18(30.5)$ & $20(33.9)$ & 2.86 & 1.02 & -0.416 & -0.983 \\
\hline & Student-content & $7(11.9)$ & $16(27.1)$ & $19(32.2)$ & $17(28.8)$ & 2.78 & 1.01 & -0.283 & -0.994 \\
\hline & Student-student & $7(11.9)$ & $17(28.8)$ & $19(32.2)$ & $16(27.1)$ & 2.75 & 0.993 & -0.226 & -0.999 \\
\hline & Autonomy & $5(8.5)$ & $14(23.7)$ & $17(28.8)$ & $23(39)$ & 2.98 & 0.991 & -0.515 & -0.884 \\
\hline & Collaboration & $7(11.9)$ & $17(28.8)$ & $20(33.9)$ & $15(25.4)$ & 2.73 & 0.980 & -0.219 & -0.948 \\
\hline & Deepening & $9(15.3)$ & $12(20.3)$ & $21(35.6)$ & $17(28.8)$ & 2.78 & 1.03 & -0.407 & -0.955 \\
\hline & Resolution & $7(11.9)$ & $18(30.5)$ & $20(33.9)$ & $14(23.7)$ & 2.69 & 0.969 & -0.165 & -0.937 \\
\hline & Class time & $3(15.3)$ & $14(23.7)$ & $21(35.6)$ & $15(25.4)$ & 2.71 & 1.01 & -0.298 & -0.983 \\
\hline & Ratings $^{\mathrm{a}}$ & $6(10.2)$ & $17(28.8)$ & $20(33.9)$ & $16(27.1)$ & 2.78 & 0.966 & -0.249 & -0.923 \\
\hline & Teacher ratings ${ }^{a}$ & $7(11.9)$ & $20(33.9)$ & $19(32.2)$ & $13(22)$ & 2.64 & 0.961 & -0.064 & -0.943 \\
\hline
\end{tabular}

The comparison of the means obtained by the control group and the experimental group gives even results, with both groups having an almost identical total mean. Of all the dimensions, motivation and autonomy in the experimental group and class time in the control group stand out, which considerably exceed the totalized mean (Figure 1).

To know the value of independence of the results obtained in flipped learning without BYOD, for the control group, and flipped learning with BYOD, for the experimental group, the Student's $t$ statistic was used for independent samples. The results show that there are only three dimensions that are statistically significant, but with different trends. On the one hand, there are the dimensions of motivation and autonomy, whose statistics show that they are significant, with a negative sign, which gives a higher value to the students in the experimental group than in the control group, with a considerable difference in means. On the other hand, there is the class time dimension, whose values indicate that it is statistically significant, but with a positive sign, indicating that the evaluations have been higher in the control group than in the experimental group. All the significant dimensions present 
a low association force, according to the biserial correlation. In addition, Cohen's $d$, which marks the size of the effect, is very low (Table 3).

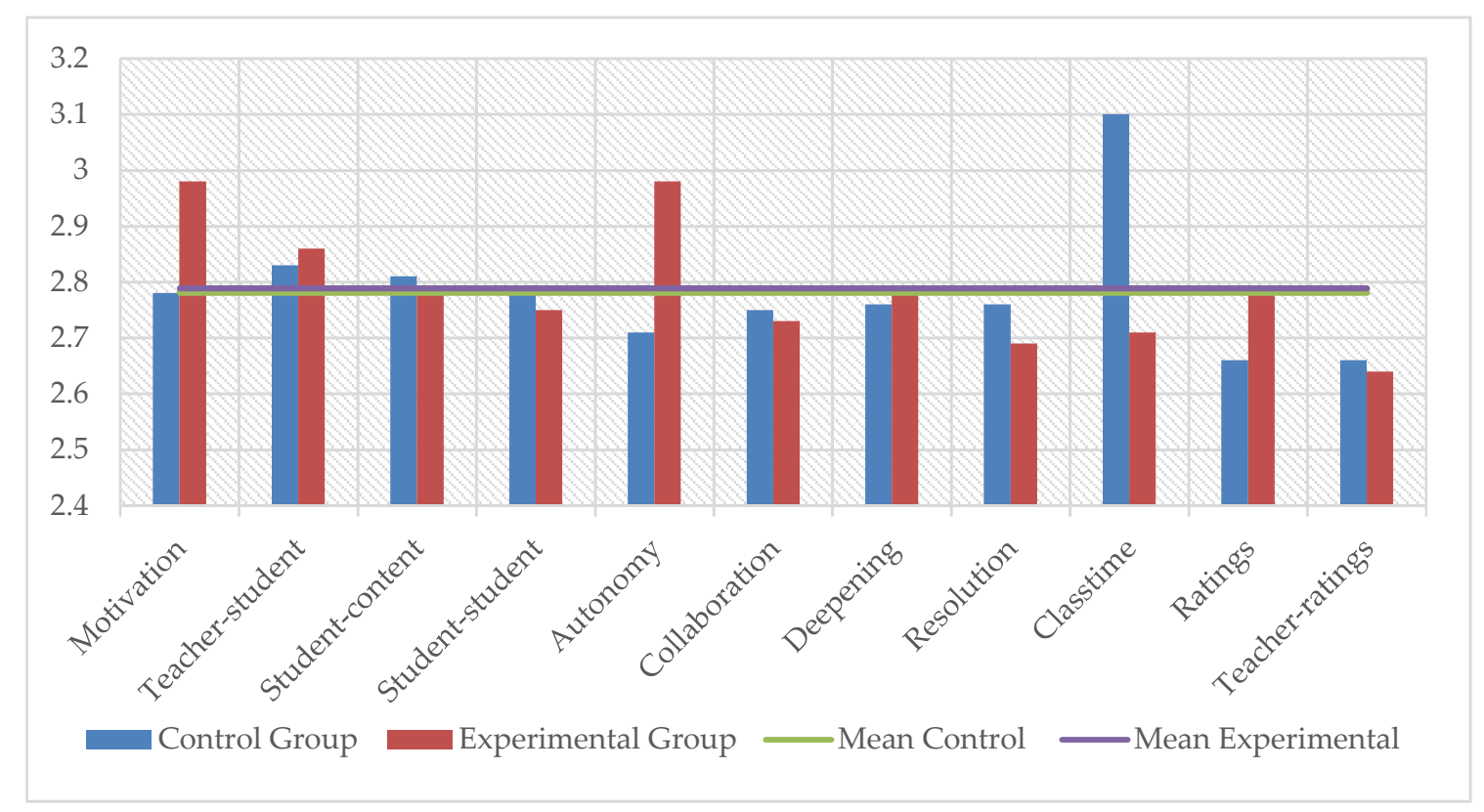

Figure 1. Comparison between control group and experimental group.

Table 3. Study of the value of independence between control group and experimental group.

\begin{tabular}{cccccc}
\hline Dimensions & $\boldsymbol{\mu}(\mathbf{X} \mathbf{1}-\mathbf{X} \mathbf{2})$ & $\mathbf{t}_{\mathbf{n} 1+\mathbf{n} 2-\mathbf{2}}$ & $\mathbf{d f}$ & $\mathbf{d}$ & $\mathbf{r}_{\mathbf{x y}}$ \\
\hline Motivation & $-0.373(2.78-3.15)$ & $-2.045^{*}$ & 116 & 0.035 & 0.187 \\
Teacher-student & $-0.034(2.83-2.86)$ & n.s. & - & - & - \\
Student-content & $0.034(2.81-2.78)$ & n.s. & - & - & - \\
Student-student & $0.034(2.78-2.75)$ & n.s. & - & - & - \\
Autonomy & $-0.373(2.71-3.08)$ & $-2.019 *$ & 116 & 0.066 & 0.184 \\
Collaboration & $0.017(2.75-2.73)$ & n.s. & - & - & - \\
Deepening & $-0.017(2.76-2.78)$ & n.s. & - & - & - \\
Resolution & $0.068(2.76-2.69)$ & n.s. & - & - & - \\
Class time & $0.390(3.10-2.71)$ & $2.141^{*}$ & 116 & -0.015 & -0.195 \\
Ratings a & $-0.119(2.66-2.78)$ & n.s. & - & - & - \\
Teacher ratings ${ }^{\text {a }}$ & $0.017(2.66-2.64)$ & n.s. & - & - & - \\
\hline
\end{tabular}

*. Correlation is significant at the 0.05 level. n.s. Not significant. ${ }^{a}$. Established grade group (None: $1-4.9$; Few: 5-5.9; Enough: 6-8.9; Completely: 9-10).

\section{Discussion}

Today's teaching is subject to great changes and the proliferation of technology-based appearances that adapt to the vanguard of society. The application of methodologies and models, such as those developed in this experimentation, are mandatory for the development of teaching, to favor the learning of students who increasingly require and request it.

From the study carried out, conclusions can be drawn that consider, only in some aspects and dimensions, its implementation in the context in which it was carried out. The evaluations of the study groups, both in the control group and in the experimental group, are located at medium-high levels. This confirms a significant incidence of the teaching and learning methods applied in both groups, as well as that extracted in other experiments of this type $[1,2,6,7,23,59,60]$.

In the study, three dimensions were observed in which a distance is shown between the evaluations of the groups. Regarding motivation and autonomy, the group that used the flipped learning methodology complemented by the BYOD program obtained positive results, in line with what 
has been established in other previous studies [12,16-18,21]. Regarding the third aspect mentioned, the class time dimension was better valued by the group that received flipped learning without the BYOD program, finding no agreement with previous studies. However, the measures of the three dimensions considerably exceed the totalized mean, as in previous studies $[28,29]$.

On the other hand, the totalized measurements in all dimensions are at an intermediate level. Furthermore, it is noteworthy that the teacher-student dimensions are located above the totalized measures, both in the control group and in the experimental group.

Regarding the motivational variable, the application of the teaching methodology based on inverted learning and complemented by the BOYD program is effective, involving students in pedagogical dynamics. This method has allowed students to be more attentive, more interested, and more involved in activities in particular and in learning processes in general $[17,18]$.

\section{Conclusions}

The measurements carried out in the motivation and autonomy dimensions can be considered significan, due to their impact on the teaching carried out by the group that was subjected to these techniques and methods [61]. The class time dimension is also significant, in this case, as it shows that the methodologies developed by the group that received flipped learning without the BYOD program has a direct impact.

In short, it can be concluded that there are no major differences between the teaching methodologies applied in the control group and those applied in the experimental group, highlighting only motivation and autonomy for the experimental group and class time for the control group. Therefore, the implementation of the flipped learning and the BYOD program are effective for the teaching and learning process, although the incidence of BYOD is limited and does not significantly affect all the skills involved in the teaching and learning process.

The limitations of this study lie in its implementation in a reduced and determined context, which is, however, sufficient to be able to draw reliable and valid conclusions. This study was developed using a quantitative research methodology using a quasi-experimental design. The data collection of the results was carried out quantitatively in all cases, but some of the variables analyzed could be considered under a qualitative perspective. Despite this, this research aims to initiate a path of research on flipped learning with BYOD and deepen it with subsequent more specific research.

The prospective of this research focuses on the controversial debate on the efficacy of complementary programs in active methodologies. The effects of the BYOD program have been studied in detail in recent years, but in many investigations, it is difficult to discern whether the positive effects are caused by BYOD itself or by the implementation of the active methodology (flipped learning, in this case). Therefore, a line of research was started in which it was found that not all the attitudinal, procedural, and aptitude benefits are directly caused by the implementation of the program, since no significant differences were observed between the two study groups.

This study will allow us to continue contributing to the scientific literature of the BYOD program in the specific context of flipped learning, an area in which there is still scope for specific research. Teachers will have a new perspective on the application of the BYOD program in students who experience the flipped learning methodology in the specific context of higher education. Likewise, teachers may have a reference framework to check the effects of its implementation in a combined flipped learning methodology complemented by BYOD on specific attitudes and skills, such as motivation, interaction, autonomy, collaboration, deepening, and problem solving, taking advantage of time and grades.

Author Contributions: Conceptualization, S.P.S., A.-J.M.-G., and J.L.-B.; methodology, J.L.-B. and S.P.S.; software, A.-J.M.-G. and S.P.S.; validation, A.-J.M.-G. and A.F.C.; formal analysis, A.F.C. and J.M.S.R.; investigation, J.L.-B., A.-J.M.-G., A.F.C., J.M.S.R., and S.P.S.; data curation, A.-J.M.-G., J.L.-B., and A.F.C.; writing-original draft preparation, J.L.-B., A.-J.M.-G., A.F.C., and S.P.S.; writing—review and editing, J.L.-B., A.-J.M.-G., A.F.C., and S.P.S.; visualization, J.M.S.R.; supervision, J.L.-B. and S.P.S. All authors have read and agreed to the published version of the manuscript. 
Funding: This research was funded by I+D+i OTRi CNT-4315. Metodologías activas para el aprendizaje mediante recursos tecnológicos para el desarrollo de la sociedad.

Acknowledgments: We acknowledge the researchers of the research group AREA (HUM-672), which belongs to the Ministry of Education and Science of the Junta de Andalucía and is registered in the Department of Didactics and School Organization of the Faculty of Education Sciences of the University of Granada.

Conflicts of Interest: The authors declare no conflict of interest.

\section{References}

1. Aznar, I.; Cáceres, M.P.; Romero, J.M. Competencia digital de un tutor e-learning: un modelo emergente de buenas prácticas docentes en TIC/Digital competence of an e-learning tutor: An emerging model of good teaching practices in ICT. Texto Livre Ling. Tecnol. 2009, 12, 49-68. [CrossRef]

2. Alonso, S.; Rodríguez, A.M.; Cáceres, M. Análisis de la Acción Tutorial y su Incidencia en el Desarrollo Integral del Alumnado. El Caso de la Universidad de Castilla La Mancha, España. Form. Univ. 2018, 11, 63-72. [CrossRef]

3. Froehlich, D.E. Non-technological learning environments in a technological world: Flipping comes to the aid. J. New Approaches Educ. Res. 2018, 7, 94-99. [CrossRef]

4. Zainuddin, Z.; Habiburrahim, H.; Muluk, S.; Keumala, C.M. How do students become self-directed learners in the EFL flipped-class pedagogy? A study in higher education. Indones. J. Appl. Linguist. 2019, 8, 678-690. [CrossRef]

5. Bergmann, J.; Sams, A. Flip Your Classroom: Reach Every Student in Every Class Every Day, 1st ed.; ISTE: Washington, DC, USA, 2012; pp. 34-40.

6. He, W.; Holton, A.; Farkas, G.; Warschauer, M. The effects of flipped instruction on out-of-class study time, exam performance, and student perceptions. Learn. Instr. 2016, 45, 61-71. [CrossRef]

7. Pozo, S.; López, J.; Moreno, A.J.; López, J.A. Impact of Educational Stage in the Application of Flipped Learning: A Contrasting Analysis with Traditional Teaching. Sustainability 2019, 11, 5968. [CrossRef]

8. Bauer, C.; Graney, J.M.; Marshall, H.W.; Sabieh, C. Flipped learning in TESOL: Definitions, approaches, and implementation. Tesol J. 2016, 7, 429-437. [CrossRef]

9. El Miedany, Y. Flipped learning. In The Flipped Classroom: Practice and Practices in Higher Education, 1st ed.; Reidsema, C., Kavanagh, L., Hadgraft, R., Smith, N., Eds.; Springer: New York, NY, USA, 2019; Volume 1, pp. 285-303. [CrossRef]

10. Long, T.; Cummins, J.; Waugh, M. Use of the flipped classroom instructional model in higher education: Instructors' perspectives. J. Comput. High. Educ. 2017, 29, 179-200. [CrossRef]

11. Schmidt, S.M.; Ralph, D.L. The Flipped Classroom: A Twist on Teaching. Contemp. Issues Educ. Res. 2016, 9, 1-6. [CrossRef]

12. Tourón, J.; Santiago, R. El modelo Flipped learning y el desarrollo del talento en la escuela. Rev. Educ. 2015, 1, 196-231. [CrossRef]

13. López, J.; Pozo, S.; Fuentes, A.; López, J.A. Creación de contenidos y flipped learning: Un binomio necesario para la educación del nuevo milenio. Rev. Española Pedagog. 2019, 77, 535-555. [CrossRef]

14. Shih, W.L.; Tsai, C.Y. Students' perception of a flipped classroom approach to facilitating online project-based learning in marketing research courses. Australas. J. Educ. Technol. 2017, 33, 32-49. [CrossRef]

15. Boelens, R.; Voet, M.; De Wever, B. The design of blended learning in response to student diversity in higher education: Instructors' views and use of differentiated instruction in blended learning. Comput. Educ. 2018, 120, 197-212. [CrossRef]

16. Chyr, W.L.; Shen, P.D.; Chiang, Y.C.; Lin, J.B.; Tsia, C.W. Exploring the effects of online academic help-seeking and flipped learning on improving students' learning. J. Educ. Technol. Soc. 2017, 20, 11-23.

17. Huang, B.; Foon, K.; Kwan, C. Investigating the effects of gamification-enhanced flipped learning on undergraduate students' behavioral and cognitive engagement. Int. Learn. Environ. 2018, 1, 1-21. [CrossRef]

18. Tse, W.S.; Choi, L.Y.; Tang, W.S. Effects of video-based flipped class instruction on subject reading motivation. Br. J. Educ. Technol. 2019, 50, 385-398. [CrossRef]

19. DeLozier, S.J.; Rhodes, M.G. Flipped classrooms: A review of key ideas and recommendations for practice. Educ. Psychol. Rev. 2017, 29, 141-151. [CrossRef] 
20. MacLeod, J.; Yang, H.H.; Zhu, S.; Shi, Y. Technological factors and student-to-student connected classroom climate in cloud classrooms. J. Educ. Comput. Res. 2017, 56, 826-847. [CrossRef]

21. Bognar, B.; Sablić, M.; Škugor, A. Flipped learning and Online Discussion in Higher Education Teaching. In The Flipped Classroom: Practice and Practices in Higher Education, 1st ed.; Reidsema, C., Kavanagh, L., Hadgraft, R., Smith, N., Eds.; Springer: New York, NY, USA, 2019; Volume 1, pp. 371-392. [CrossRef]

22. Karabulut, A.; Jaramillo, N.; Hassall, L. Flipping to engage students: Instructor perspectives on flipping large enrolment courses. Australas. J. Educ. Technol. 2018, 34, 123-137. [CrossRef]

23. Awidi, I.T.; Paynter, M. The impact of a flipped classroom approach on student learning experience. Comput. Educ. 2019, 128, 269-283. [CrossRef]

24. Hinojo, F.J.; Aznar, I.; Romero, J.M.; Marín, J.A. Influencia del aula invertida en el rendimiento académico. Una revisión sistemática. Campus Virtuales 2019, 8, 9-18.

25. Sola, T.; Aznar, I.; Romero, J.M.; Rodríguez, A.M. Eficacia del método flipped classroom en la universidad: Meta-análisis de la producción científica de impacto. REICE 2019, 17, 25-38. [CrossRef]

26. Hwang, G.J.; Lai, C.L.; Wang, S.Y. Seamless flipped learning: A mobile technology-enhanced flipped classroom with effective learning strategies. J. Comput. Educ. 2015, 2, 449-473. [CrossRef]

27. Mengual, S.; López, J.; Fuentes, A.; Pozo, S. Modelo estructural de factores extrínsecos influyentes en el flipped learning. Educ. XX1 2020, 23, 75-101.

28. López, J.; Pozo, S.; Del Pino, M.J. Projection of the Flipped Learning Methodology in the Teaching Staff of Cross-Border Contexts. NAER 2019, 8, 184-200. [CrossRef]

29. Yilmaz, A.; Soyer, F. Effect of Physical Education and Play Applications on School Social Behaviors of Mild-Level Intellectually Disabled Children. Educ. Sci. 2018, 8, 89. [CrossRef]

30. Elmer, G.; Trujillo, J.M.; Cáceres, M.P.; Soler, R. Using and integration of ICT in a diverse educational context of Santander (Colombia). J. Technol. Sci. Educ. 2018, 8, 254-267. [CrossRef]

31. Ameen, N.; Tarhini, A.; Shah, M.H.; Madichie, N.O. Employees' behavioural intention to smartphone security: A gender-based, cross-national study. Comput. Human Behav. 2020, 104, 1-13. [CrossRef]

32. Afreen, R. Bring your own device (BYOD) in higher education: Opportunities and challenges. Int. J. Emerg. Trends Technol. Comput. Sci. 2014, 3, 233-236.

33. Almerich, G.; Suárez-Rodríguez, J.; Díaz-García, I.; Orellana, N. Estructura de las competencias del siglo XXI en alumnado del ámbito educativo. Factores personales influyentes. Educ. XX1 2020, 23, 45-74. [CrossRef]

34. Livas, C.; Katsanakis, I.; Vayia, E. Perceived impact of BYOD initiatives on post-secondary students' learning, behaviour and wellbeing: The perspective of educators in Greece. Educ. Inform. Technol. 2019, 24, 489-508. [CrossRef]

35. Cheng, G.; Guan, Y.; Chau, J. An empirical study towards understanding user acceptance of bring your own device (BYOD) in higher education. Australas. J. Educ. Technol. 2016, 32,1-17. [CrossRef]

36. Song, Y. “Bring Your Own Device (BYOD)" for seamless science inquiry in a primary school. Comput. Educ. 2014, 74, 50-60. [CrossRef]

37. Parsons, D.; Adhikar, J. Bring Your Own Device to Secondary School: The Perceptions of Teachers, Students and Parents. Electron. J. E Learn. 2016, 14, 66-80.

38. Hung, H.T. Clickers in the flipped classroom: Bring your own device (BYOD) to promote student learning. Interact. Learn. Environ. 2017, 25, 983-995. [CrossRef]

39. Hao, Y. Exploring undergraduates' perspectives and flipped learning readiness in their flipped classrooms. Comput. Human Behav. 2016, 59, 82-92. [CrossRef]

40. Nuhoglu, P.; Gundiz, A.Y.; Akkoyunlu, B. Implementing Bring Your Own Device (BYOD) Model in Flipped Learning: Advantages and Challenges. Technol. Knowl. Learn. 2019, 1-14. [CrossRef]

41. Song, Y.J.; Wen, Y. Integrating Various Apps on BYOD (Bring Your Own Device) into Seamless Inquiry-Based Learning to Enhance Primary Students' Science Learning. J. Sci. Educ. Technol. 2018, 27, 165-176. [CrossRef]

42. Sorotiva, A.; Schneider, E.M.; Danhoni, M.C.; Rutz, S.C. Human rights, violences and educational policies: The BOYD movement contribution in the initial training of biological science teachers. Rev. Educ. Soc. 2019, $6,206-222$.

43. Welsh, K.E.; Mauchline, A.L.; France, D.; Powell, V.; Whalley, W.B.; Park, J. Would Bring Your Own Device (BYOD) be welcomed by undergraduate students to support their learning during fieldwork? J. Geogr. High. Educ. 2018, 42, 356-371. [CrossRef] 
44. Stonebraker, I.R.; Robertshaw, M.B.; Kirkwood, H.P.; Dugan, M. Bring Your Own Device in the Information Literacy Classroom. Indiana Libr. 2014, 33, 64-67.

45. Hernández, R.; Fernández, C.; Baptista<sc>, M.P. Metodología de la Investigación, 6th ed.; McGraw Hill: Madrid, Spain, 2014; pp. 129-168.

46. Rodríguez, N. Diseños experimentales en educación. REP 2011, 32, 147-158.

47. Hinojo, F.J.; López, J.; Fuentes, A.; Trujillo, J.M.; Pozo, S. Academic Effects of the Use of Flipped Learning in Physical Education. Int. J. Environ. Res. Public Health 2020, 17, 276. [CrossRef]

48. López, J.; Fuentes, A.; López, J.A.; Pozo, S. Formative Transcendence of Flipped Learning in Mathematics Students of Secondary Education. Mathematics 2019, 7, 1226. [CrossRef]

49. López, J.A.; López, J.; Moreno, A.J.; Pozo, S. Effectiveness of Innovate Educational Practices with Flipped Learning and Remote Sensing in Earth and Environmental Sciences-A Case Study. Remote Sens. 2020, 12, 897. [CrossRef]

50. López-Belmonte, J.; Segura-Robles, A.; Fuentes-Cabrera, A.; Parra-González, M.E. Evaluating activation and absence of negative effect: Gamification and Escape Rooms for learning. Int. J. Environ. Res. Public Health 2020, 17, 2224. [CrossRef]

51. Moreno-Guerrero, A.J.; Romero-Rodríguez, J.M.; López-Belmonte, J.; Alonso-García, S. Flipped Learning Approach as Educational Innovation in Water Literacy. Water 2020, 12, 574. [CrossRef]

52. Moreno-Guerrero, A.J.; Rondón, M.; Martínez, N.; Rodríguez-García, A.M. Collaborative Learning Based on Harry Potter for Learning Geometric Figures in the Subject of Mathematics. Mathematics 2020, 8, 369. [CrossRef]

53. Chou, P.N.; Feng, S.T. Using a Tablet Computer Application to Advance High School Students' Laboratory Learning Experiences: A Focus on Electrical Engineering Education. Sustainability 2019, 11, 381. [CrossRef]

54. Parra-González, M.E.; López, J.; Segura-Robles, A.; Fuentes, A. Active and Emerging Methodologies for Ubiquitous Education: Potentials of Flipped Learning and Gamification. Sustainability 2020, 12, 602. [CrossRef]

55. Driscoll, T. Flipped Learning and Democratic Education. Graduate Thesis, Columbia University, New York, NY, USA, 2012.

56. Martín, D.; Sáenz, M.; Santiago, R.; Chocarro, E. Diseño de un instrumento para evaluación diagnóstica de la competencia digital docente: Formación flipped classroom. DIM 2016, 1, 1-15.

57. Santiago, R.; Bergmann, J. Aprender al revés, 1st ed.; Paidós Educación: Barcelona, Spain, 2018; pp. $133-142$.

58. Jöreskog, K.G. Analysis of Ordinal Variables 2: Cross-Sectional Data. Text of the workshop "Structural Equation Modelling with LISREL 8.51"; Friedrich-Schiller-Universität Jena: Jena, Germany, 2001; pp. 116-119.

59. Álvarez-Rodríguez, M.D.; Bellido-Márquez, M.D.; Atencia-Barrero, P. Teaching though ICT in Obligatory Secundary Education. Analysis of online teaching tools. RED 2019, 1, 1-19. [CrossRef]

60. Khine, M.S.; Ali, N.; Afari, E. Exploring relationships among TPACK constructs and ICT achievement among trainee teachers. Educ. Inf. Technol. 2017, 22, 1605-1621. [CrossRef]

61. Cuevas, R.E.; Feliciano, A.; Alarcón, A.; Catalán, A.; Alonso, G.A. The integration of ICT tools to the profile of the Computer Engineer of the Autonomous University of Guerrero, Mexico. Virtualidad Educ. Cienc. 2019, $10,20-32$.

(C) 2020 by the authors. Licensee MDPI, Basel, Switzerland. This article is an open access article distributed under the terms and conditions of the Creative Commons Attribution (CC BY) license (http://creativecommons.org/licenses/by/4.0/). 